\title{
Distemper virus-induced apoptotic changes in cerebellum
}

\author{
Sevil ATALAY VURAL ${ }^{1}$, Mehmet Eray ALCIGIR ${ }^{2}$ \\ ${ }^{1}$ Department of Pathology, Faculty of Veterinary Medicine, Ankara University, Ankara, Turkey, ${ }^{2}$ Department of Pathology, \\ Graduate School of Health Science, Ankara University, Ankara, Turkey.
}

\begin{abstract}
Summary: In the study, it was purposed that detection of apoptotic changes with terminal deoxynucleotidyl transferase (TdT)-mediated dUTP-digoxigenin nick end-labelling (TUNEL) method in the cerebellum of 10 dogs (n:3 females, n:7 males), varied 3 months to 2.5 years-old, different breed (1 Husky, 9 Mongrel) and sex (3 females, 7 males) in distemper disease. Histopathologically, acute (n:4) and chronic (n:6) nonpurulent encephalitis, moderate and/or mild demyelination, and intranuclear inclusion bodies were seen. Immunohistochemically distemper virus antigen was also detected in demyelinated white matter, astrocytes, and inclusion bodies in all dogs by using monoclonal canine distemper virus nucleoprotein sera. Morphologically multiple consendations of nuclear chromatin in astrocytes were found with Cresyl violet stain. TUNEL reaction in markedly astrocytes localized surrounding the demyelination areas, rarely inclusion bodies, gemistocytic astrocytes, Gitter cells in white matter and granular layer of cerebellum was demonstrated. The reactions in chronic inflammatory lesions were also detected in perivascular mononuclear cells.
\end{abstract}

Key words: Dog, distemper virus, apoptosis, TUNEL

\section{Distemper virusuna bağlı serebellumda oluşan apoptotik değişiklikler}

Özet: Bu çalışmada, canine distemper virusu belirlenen 3 ay-2.5 yaşlı, değişik ırk (1 Husky, 9 melez) ve cinsiyetteki (3 dişi, 7 erkek) 10 adet köpeğin serebellumunda TUNEL (terminal deoxynucleotidyl transferase (TdT)-mediated dUTP-digoxigenin nick endlabeling) metodu ile gözlenen apoptotik değişiklikler araştırıldı. Histopatolojik incelemede 4 hayvanda akut, 6 hayvanda da kronik nonpurulent ensefalitise ve demyelinasyona (hafif ve/veya orta şiddette) ilgili bulgular gözlendi. Monoclonal canine distemper virus nucleoprotein serumu kullanılarak yapılan immunohistokimyasal boyamada demyelinize beyaz maddede, astrositlerde ve inkluzyon cisimciklerinde distemper virusu antijeni saptandı. Morfolojik olarak Cresyl violet boyamasında, astrositlerde kromatinin kaba partiküller halinde çekirdek membranına yakın olarak toplandığı görüldü. TUNEL metodu ile yapılan boyamalarda ise akut olgularda daha yoğun olmak üzere özellikle demyelinize alanların etrafında bulunan astrositlerde, daha nadir olarak da inkluzyon cisimciklerinde, gemistositik astrositlerde, Gitter hücrelerinde, granuler tabaka hücrelerinde ve perivasküler mononüklear hücrelerde apoptotik değişiklikler saptand.

Anahtar sözcükler: Apoptozis, distemper virus, köpek, TUNEL.

\section{Introduction}

Paramyxoviruses are responsible for a wide variety of disease both in pet animals (e.g. canine distemperCD), livestocks (e.g. rinderpest, Newcastle disease) and humans (e.g. measles). CD is a contagious multisystemic disease which often with viral spread to central nervous system (CNS) resulting from acute to chronic multifocal demyelinating encephalitis in dogs and its relatives. Canine distemper virus (CDV) infects in the first year of their life, but puppies are more susceptible. Clinical findings can be varied in severity and range. In some of dogs occur neurological findings combined with following subclinical or systemic disorder $(19-21,23)$.

Apoptosis is a distinct mechanism of cell death which can be induced by a variety of internal and external stimuli. This process serves as primarily to eliminate cells during normal development and immune cell selection as well as cells that have sustained genetic damage. Apoptotic cells are characterized by specific changes in cell morphology, including cytoplasmic shrinkage, chromatin condensation, and eventually fission into multiple, membrane-bound apoptotic bodies. Since apoptotic cells remain membrane bound and are generally phagocytosed by resident macrophages, apoptosis is seldom associated with an inflammatory response. In contrast to necrotic cell death, which occurs in response to acute cellular damage, it is characterized by cellular alterations that differ from those characteristic of apoptosis including cell swelling, random degredation of chromatin, and eventually lysis (12). Apoptosis plays a central role in hemostasis of all multicellular organism by eliminating dangerous cells such as mutant or viral infected (22). Recent studies have shown that some viruses including reovirus, influenza virus, rabies virus, 
measles virus, and alpha virus cause cell death through the induction of apoptosis $(7,10,13,14,16)$. In the case of $\mathrm{CDV}$, cell death is observed during the infection (15). Some searchers reported that CD causes apoptosis in the brain and lymph nodes $(7,12,13)$.

In the study, it was aimed that detection of apoptotic changes with TUNEL method in the cerebellum of infected dogs with CDV.

\section{Material and methods}

Animals: The materials of the study are ten dogs which have infected CDV. The dogs euthanized were varied 3 months to 2.5 years old and different breed (1 Husky, 9 Mongrel) and sex ( 3 females, 7 males). They showed systemic or neurological findings of canine distemper.

Sample collection and histopathological examinations : The cerebellums were fixed in $10 \%$ buffered formaline, processed by routine method and embedded in paraffin. The sections were cut $5 \mu \mathrm{m}$, mounted on glass slides, and stained with Hematoxyline-Eosin (HE) stain. Selected the sections were also stained with Luxol Fast Blue (LFB) and Cresyl violet stains.

Immunoperoxidase staining: Sections were stained for CDV antigen by Avidin-Biotin Complex Peroxidase (ABC-P) method using monoclonal canine distemper virus nucleoprotein sera (1:500 / VMRD) as catalog procedure (LSAB Kit, Dako). As a control, samples were treated with normal mouse sera instead of primary antibody.

In-situ detection of apoptotic cells by TUNEL assay: DNA fragmentation was assessed in situ in sections of infected animals using the terminal deoxynucleotidyl transferase (TdT)-mediated dUTP-digoxigenin nick endlabelling (TUNEL) method used as catalog procedure (In Situ Cell Death Detection Kit, POD, Roche). To visiualize reaction products, samples were incubated with AEC (3Amino 9-Ethyl Carbasole, Dako), and counterstained with Gill's hematoxyline stain. As a control, samples were treated with labeling solution instead of TdT.

\section{Results}

Histopathologically, two types findings were seen; acute (n:4) and chronic (n:6) nonpurulent encephalitis such as reported by Schobesberger et all (18). Acute encephalitis was characterized by moderate demyelination, intranuclear inclusion bodies, gliosis, gemistocytic astrocytes, and Gitter cells in white matter (fig. 1-2). In chronic encephalitis, the inflammatory mononuclear cells were prominent. Lymphocytes accumulated around blood vessels forming multi-layered perivascular cuffs together with acute encephalitis findings. Demyelinated areas in both of stages were moderate and/or mild stained with LFB stain.

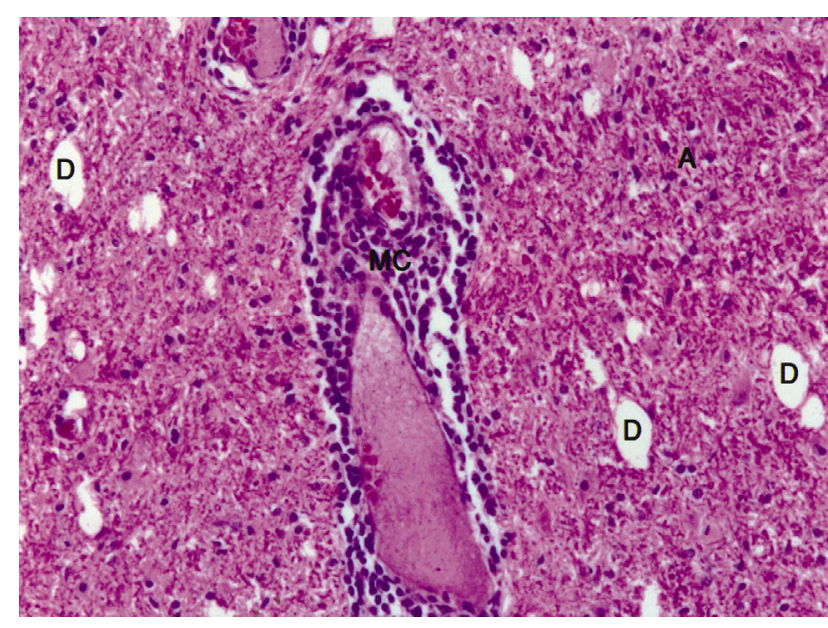

Figure 1. Perivascular mononuclear cell (MC) infiltration, astrogliosis (A) and demyelinated areas (D), HE, x40.

Şekil 1. Perivaskuler mononuklear hücre (MC) infiltrasyonu, astrogliozis (A) ve demyelinize alanlar (D), HE x40.

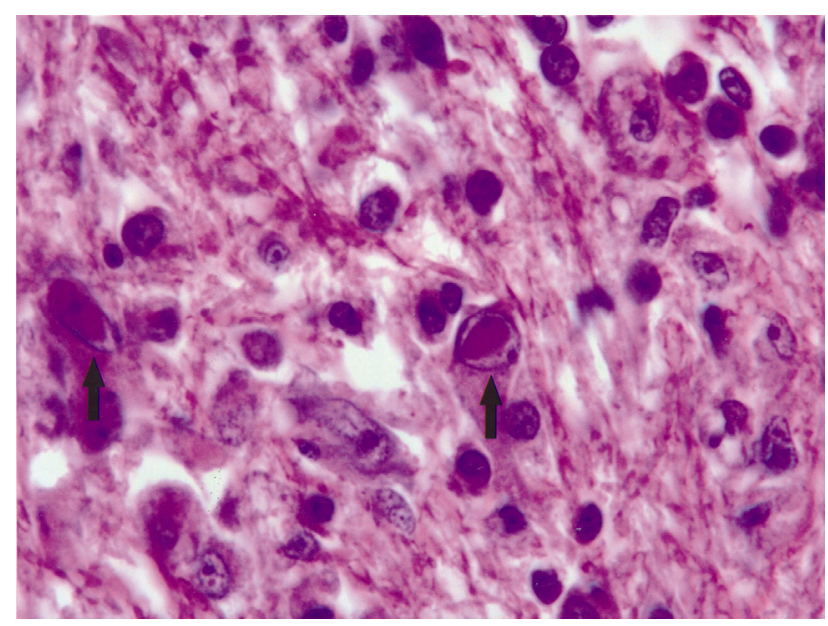

Figure 2. Intranuclear inclusion bodies in astrocytes in substantia alba (arrows), HE x400.

Şekil 2. Substansia alba'da astrositlerde intra nuklear inkluzyon cisimcikleri (oklar), HE x400.

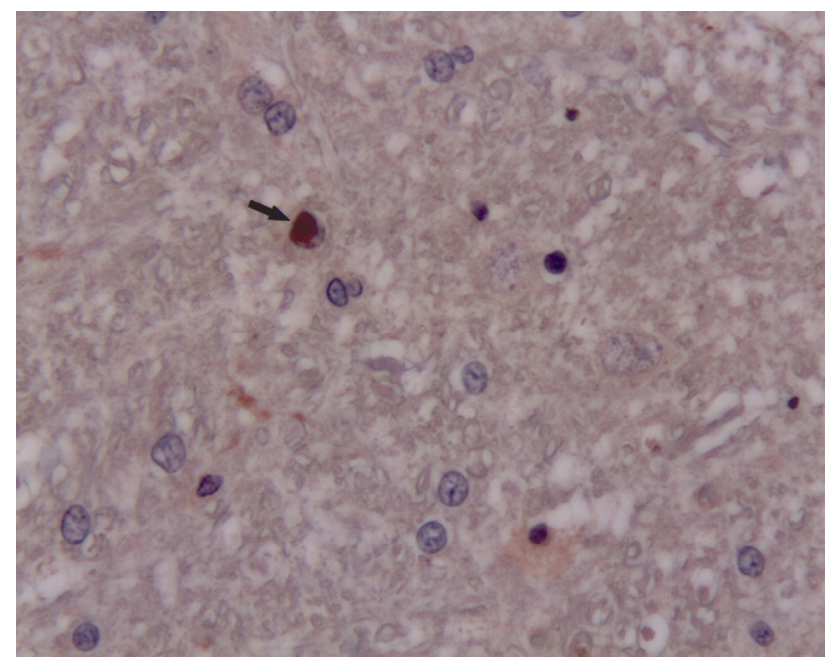

Figure 3. CDV positivity in inclusion body (arrow), ABC-P $\mathrm{x} 200$.

Şekil 3. İnkluzyon cisimciğinde CDV pozitifliği (ok), ABC-P $\mathrm{x} 200$ 


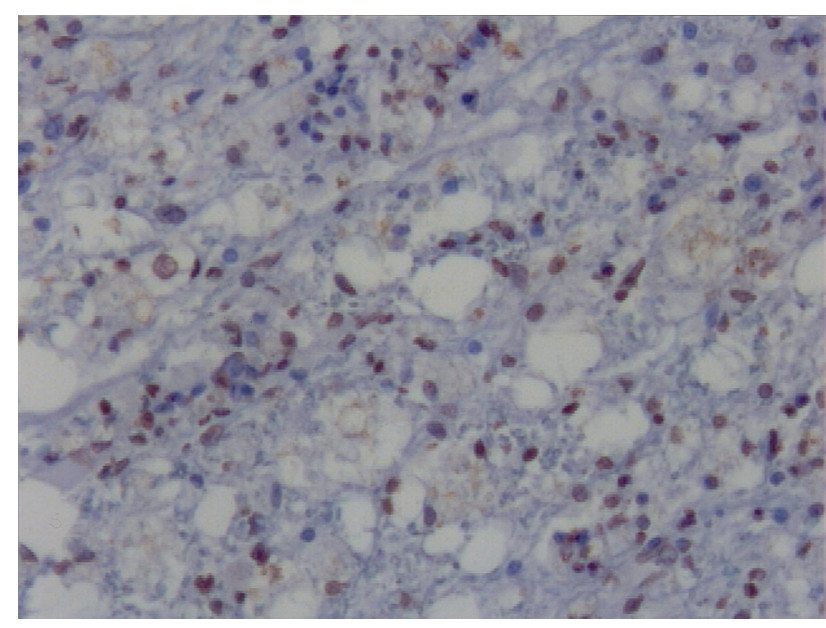

Figure 4. Apoptotic astrocytes, TUNEL stain, x100. Şekil 4. Apoptotik astrositler, TUNEL boyama x100.

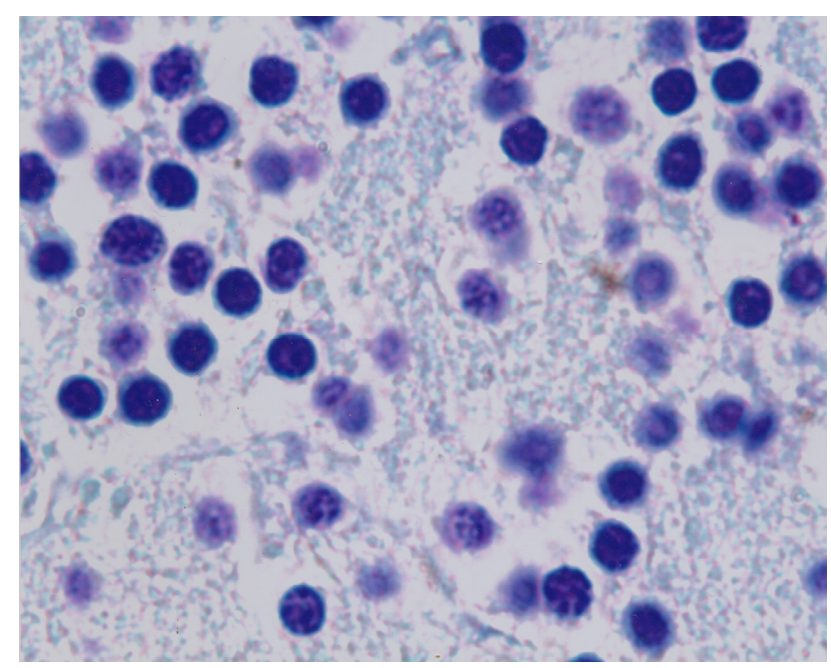

Figure 5. Multiple condensations of nuclear chromatin in granular cells, Cresyl violet, x100.

Şekil 5. Granular hücrelerde çekirdek kromatininin çoklu yoğunlaşması, Cresyl violet, x100.

Immunohistochemically, CDV antigen was detected in demyelinated white matter, astrocytes, and inclusion bodies (fig. 3) in some areas.

Morphologic changes of apoptosis were found in white matter and granular layer of cerebellum. TUNEL reaction in remarkably astrocytes (fig. 4), rarely inclusion bodies, gemistocytic astrocytes, and Gitter cells in white matter and granular layer of cerebellum was demonstrated. The staining was significantly less severe in chronic infection than acute infection in similar areas. The astrocytes seeing TUNEL reaction were markedly localized surrounding the demyelination areas. Also TUNEL reactions in the chronic inflammatory lesions were presumably seen in the perivascular mononuclear cells. Multiple consendations of nuclear chromatin in astrocytes and granular cells were seen in Cresyl violet stain (fig. 5).

\section{Discussion and Conclusion}

The study was demonstrated which detection of apoptotic changes with TUNEL method in the cerebellum of dogs with CD encephalitis. The microscopical lesions seen in the study were characteristic and similar to reported by researchers for acute noninflammatory and chronic inflammatory demyelination $(8,9,18,19)$. The initial acute demyelinating lesion, preceding inflammatory destruction of the white matter, correlates with virus replication in brain cells, especially astrocytes and appears to be directly virus induced (20). The occurrence of segmental demyelination in these early lesions in distemper suggests a primary involvement of the oligodendrocytes, the myelin-producing cells $(4,9)$. But, the mechanism of oligodendroglial degeneration in CD has remained uncertain $(3,23)$. Inflammatory demyelination in the chronic stage of CDV infection is most probably due to a "by-stander" effect resulting from interactions between the antiviral immune response and macrophages (6). The virus causes multifocal lesions in the gray matter as well as in the white matter of the CNS (20). The demyelinating lesions are not only responsible for severe neurological signs but are also thought to be a model for human demyelinating conditions such as multiple sclerosis (2). Therefore, the pathogenesis of demyelination in CD has been investigated closely in recent years. The number of detailed studies about the neuropathogenesis of CDV that have been carried out might therefore give some insight into similar disease patterns among the emerging paramyxoviruses.

Apoptosis has been recently recognized to be an important mechanism of cell death in diverse pathologic conditions including viral infections. There is increasing evidence that apoptosis has an important role in the pathogenesis of a variety of viral infections of the CNS $(5,10,11,16)$. CDV occur a multifocal demyelinating disease (21). Initial demyelination in distemper encephalitis is directly virus induced $(21,23)$. Demyelination in distemper is thought to be due to a selective alteration of the oligodendrocytes. The pathogenic mechanism of oligodendrocytes impairment in demyelinating disease are still not fully understood $(3,17)$. Apoptosis was discussed as a possible mechanism of oligodendrocytes loss in demyelinating diseases, and oligodendrocytes were shown to undergo apoptosis after various stimuli in vitro (17). Vandevelde et all (21) reported that granular cells of the cerebellum were dyed in apoptosis. Those areas with several apoptotic granular cells were surrounded by white matter with demyelinated plaques. It is suggested that granular cells might enter apoptosis through direct lesion by CDV and secondary lesion as a result of previous glial cells impairment. Some searchers $(13,14)$ reported apoptosis in astrocytic syncytia in vitro unlike these studies. Moro et all (14) reported TUNEL 
reaction in inclusion bodies, several gemistocytes, Gitter cells in white matter and the granular layer of grey matter.

In the study, we seen TUNEL reaction generally in glial cells, and perivascular mononuclear cells. In some areas, apoptotic cells were rarely detected in granular layer of the cerebellum. Also Schobesberger et all (18) described apoptotic cells detected in some areas and this position was thought defence mechanism for virus.

In the study, typical morphological changes in glial cells especially astrocytes included multiple discrete clumps of nuclear chromatin. TUNEL staining was markedly in the astrocytes with staining in only a number of inflammatory cells. These cells are related to virus elimination from CNS and can increase lesion severity and cellular cytotoxity against virus-infected cells $(1,21)$. In also, the astrocytes are main target for CDV.

A greater understanding of the mechanism responsible for the induction of apoptosis in $\mathrm{CD}$ and other viral infections will be useful in the development of new therapeutic strategies for the management of these infections.

\section{Acknowledgement}

The authors thank Dr Yavuz Ulusoy for providing monoclonal antibody, The Clinics of Faculty and Private Clinics for obtaining the materials.

\section{References}

1. Bollo E, Zurbriggen A, Vandevelde M, Fankhauser $\mathbf{R}$ (1986): Canine distemper virus clearance in chronic inflammatory demyelination. Acta Neuropathol, 72, 69-73.

2. Bonetti B, Raine CS (1997): Multiple sclerosis: Oligodendrocytes display cell death-related molecules in situ but do not undergo apoptosis. Ann Neurol, 42, 74-84.

3. Glaus T, Griot C, Richard A, Althaus U, Herschkowitz N, Vandevelde M (1990): Ultrastructural and biochemical findings in brain cell cultures infected with canine distemper virus. Acta Neuropathol, 80, 59-67.

4. Graber HU, Muller CF, Vandevelde M, Zurbriggen A (1995): Restricted infection with canine distemper virus leads to down regulation of myelin gene transcription in cultured oligodendrocytes. Acta Neuropathol, 90, 312-318.

5. Granville DJ, Carthy CM, Hunt DW, McManus BM (1998): Apoptosis: Molecular aspects of cell death and disease. Lab Invest, 78, 893-913.

6. Griot C, Bürge T, Vandevelde M, Peterhans E (1989): Antibody-induced generation of reactive oxygen radicals by brain macrophages in canine distemper encephalitis: $A$ mechanism for by-stander demyelination. Acta Neuropathol, 78, 396-403.

7. Guo A, Lu CP (2000): Canine distemper virus causes apoptosis of Vero cells. J Vet Med B, 47, 183-190.

8. Headley SA, Soares IC, Graca DL (2001): Glial Fibrillary Acidic Protein (GFAP) - immunoreactive astrocytes in dogs infected with canine distemper virus. $\mathrm{J}$ Comp Path, 125, 90-97.
9. Higgins RJ, Krakowka SG, Metzler AE, Koestner A (1982): Primary demyelination in experimental canine distemper virus induced encephalomyelitis in gnotobiotic dogs. Acta Neuropathol, 58, 1-8.

10. Jackson AC, Rossiter JP (1997): Apoptosis plays an important role in experimental rabies virus infection. $\mathrm{J}$ Virol, 71, 5603-7.

11. Lewis J, Wesselingh SL, Griffin DE, Hardwick JM (1996): Alphavirus-induced apoptosis in mouse brains correlates with neurovirulence. J Virol, 70:1828-1835.

12. Majno G, Joris I (1995): Apoptosis, oncosis, and necrosis. An overview of cell death. Am J Pathol, 146, 3-15.

13. Moro L, Martins AS, Alves CM, Santos FGA, Del Puerto HL, Vasconcelos AC (2003a): Apoptosis in the Cerebellum of Dogs with Distemper. J Vet Med B, 50, 221-225.

14. Moro L, Martins AS, Alves CM, Santos FG, Del Puerto HL, Santos Nunes JE, Carneiro RA, Carvalho R, Vasconcelos AC (2003b): Apoptosis in Canine Distemper. Arch Virol, 148,153-164.

15. Nishi T, Tsukiyama-Kohara K, Togashi K, Kohriyama N, Kai C (2004): Involvement of apoptosis in syncytial cell death induced by canine distemper virus. Comp Immunol Microbiol Infect Dis, 27, 445-455.

16. Oberhaus SM, Smith RL, Clayton GH, Dermody TS, Tylor KL (1997). Reovirus infection and tissue injury in the mouse central nervous system are associated with apoptosis. J Virol, 71, 2100-2106.

17. Richter-Landsberg C, Vollgraf U (1998): Mode of cell injury and death after hydrogen peroxide exposure in cultured oligodendroglia cells. Exp Cell Res, 244, 218229.

18. Schobesberger M, Zurbriggen A, Summerfield A (1999): Oligodendroglial degeneration in distemper: Apoptosis or necrosis? Acta Neuropathol, 97, 279-287.

19. Schobesberger M, Zurbriggen A, Doherr MG, Weissenböck H, Vandevelde M, Lassmann H, Griot C (2002): Demyelination precedes oligodendrocyte loss in canine distemper virus-induced encephalitis. Acta Neuropathol, 103, 11-19.

20. Summers BA, Apel MJG (1994): Aspects of canine distemper virus and measles virus encephalomyelitis. Neuropathol Appl Neurobiol, 20, 525-534.

21. Vandevelde M, Zurbriggen A, Higgins RJ, Palmer D (1985): Spread and distrubution of viral antigen in nervous canine distemper. Acta Neuropathol, 67, 211-218.

22. Verhagen AM, Voux DL (1999): Molecular mechanism of apoptosis. Res Problems Cell Differ, 23, 10-24.

23. Zurbriggen A, Schmid I, Graber HU, Vandevelde M (1998): Oligodendroglial pathology in canine distemper. Acta Neuropathol, 95, 71-77.

Geliş tarihi: 01.05.2008 / Kabul tarihi: 16.08.2009
Adress for correspondence
Sevil ATALAY VURAL, Prof.Dr.
Department of Pathology, Faculty of Veterinary Medicine, Ankara University, 06110, Diskapi, Ankara, TURKEY
E-mail:sevilvural@yahoo.com. svural@veterinary.ankara.edu.tr Tel: +90 312-3170315 / 276
Fax: +90 312-3164472 